\title{
SOME PHILOSOPHICAL CONSIDERATIONS ON PAIN ${ }^{\dagger}$
}

\author{
J. J. DEGENAAR* D.Phil. (Stellenbosch)
}

\author{
I have put on these masks to show \\ you my face \\ Maurice English
}

\section{INTRODUCTION}

1 thought I knew what pain was until I was asked to say what the word "pain" means. Then, as is usual to such cases, I realised my ignorance. However, I in such think this is an isolated experience or an experience peculiar to philosophers. It is a common experience, it applies to many everyday words and no person who tries to define such words escapes the pobering effect of this basic human ignorance. The soint of these remarks is not to apologise in advance point the quality of this paper, but to draw our attention the difficulty of defining everyday words in spite of the fact that the experiences referred to by such words are very much part of our lives. And, as in the case of the feeling of pain, it can be very crucial to our lives. In the words of Petrie (1967:1): "There is nothing in human experience more central than our capacity to feel, and no aspect of this so crucial as our capacity to suffer, perhaps more particularly to suffer from extremes of physical pain." And even if one would like to add other capacities equally central to human experience these additions would not, 1 think, detract from the disrupting nature of suffering in the lives of men.

In concerning oneself philosophically with the concept of pain, there are different ways of approaching the problem. One can, for example, take account of the various theories of pain, whether neurological, psychological or philosophical, and on the basis of this research construct one's own theory; or one can construct a model which illuminates the experience of pain as well as the various theories of pain; or show that more basic than these theories of pain is a philosophical anthropology, a view of man, assumed by these theories; or explore the problem of pain in terms of the body-mind relationship, that is, in terms of dichotomy, interaction or identity between body and mind; ir look at the discussion of pain in analytical circles A which problems related to the privacy of sensations and the knowledge of other minds are brought to the fore; or discuss the existentialist approach to pain in terms of suffering as an expression of the human condition; or explore the meaning of the term etymologically, pain being derived from poena (Latin) which means punishment; or assess the moral approach to pain as a necessary condition for the growth of personality; or look at the problems related to a theodicy, for example, the logical links between concepts such as pain, evil and sin, and the justification of a good God with regard to an evil creation; or compare the different ways in which the religions of the world have treated the problems of pain and suffering.

I mention these various ways of approaching the problem of pain not to create the impression that I am capable of following them all, but to draw your attention to what can be included under the heading of philosophical considerations on pain. My modest task

- Head Department of Political Philosophy, University of Stellenbosch.

+ Paper read at Pain Symposium, preceding 13th National Council Meeting 23-27 April 1979. in this paper is to look at some descriptions of pain and to construct a model which will, I hope, throw some light on the experience of pain. In order to achieve this, I must first pay attention to the problem of method and to the fact that a plurality of descriptions of pain is possible. This analysis will then be followed by a discussion of the neurological, psychological and philosophical language-games, illustrating in each case the nature and value of these games in presenting us with descriptions of pain. In conclusion I propose looking at some implications of this more comprehensive view for our approach to the problem of pain in respect of theory and practice.

\section{PLURALITY OF DESCRIPTIONS}

One of the first things that strikes one in one's research on pain is the fact that different groups of people talk about pain in different terms and in different contexts. Neurologists speak in terms of nerve impulses, psychologists in terms of emotional qualities, philosophers in terms of sensations, feeling, suffering and meaning, and theologians in terms of guilt and punishment. It would be a mistake for one of these groups to think that their use of the word in their chosen context, their language-game, is the only valid one. This illustrates an important philosophical point, namely, that words are not only used to refer to things in a one-to-one correspondence, but that people operate multifariously with words and that one must take into account the different contexts in which words behave according to contextual rules. This is what is meant by the language-game in which a word operates. This contextualisation of statements in order to gauge the meaning of words is not an impoverishment of understanding. On the contrary, it is an enriching activity as I would like to show in my analysis of the concept of pain. For the more one can accommodate valid descriptions of pain, the better one's understanding of the concept.

This point about the pluralism of descriptions is also made by Sternbach (1970). He states that we become prisoners of the words we use to describe pain with the result that we are "unable to free ourselves from the words to come up with a fresh description". He points out that one's choice of a definition depends on one's profession, and mentions the following nine descriptions: pain is an elementary sensation, a complex perception, an affect (emotion), a neurophysiological activity, a neurochemical stress reaction, reflex adaptive behaviour, the result of internal psychic conflicts, interpersonal manipulation, and the human condition. Melzack (1973) is also struck by the variety of phenomena which one has to take into account in understanding the meaning of the word "pain". According to him: "the word 'pain' represents a category of experiences, signifying a multitude of different, unique events having different causes, and characterised by different qualities varying along a number of sensory and affective dimensions." Instead of saying that the word "pain" represents a category of experiences or that it is a "linguistic label for a rich variety of experiences and responses" (Melzack and Wall, 1968). Sternbach prefers to say that pain is an abstract term which refers to many different phenomena from which one makes a selection, depending on whether one is, for example, giving a neurological, physiological, behavioural, subjective or psychiatric description. 
Sternbach's approach is philosophically important because he concerns himself with a basic epistemological problem, that is, a problem related to the theory of knowledge. The expression "linguistic parallelism" is introduced by him to describe this approach which allows one word to be used to refer to different phenomena. According to this view "none of these events has any inherent relationship to one another. It is we who have arbitrarily imposed on all of them the common concept 'pain'. If we can remember that there is no single real thing that is pain, but rather that 'pain' is an abstract, unifying concept that we ourselves have arbitrarily imposed on a great many different kinds of things, then perhaps we can free ourselves to think and deal more effectively with problems when they arrive. There need not be any arguments about which is the 'right' approach, because all these parallel approaches are 'right'. That is, each describes some different things in different ways, and each approach is internally consistent and follows the rules of its own game of investigation." (Sternbach, 1970).

On the basis of this approach he constructs a useful schema which illustrates the varieties of tactics for treating chronic pain. It gives one at the same time a good idea of the variety of phenomena covered by the concept of pain.

The schema (Sternbach, 1970) is as follows.

neurological

surgery
analgesia
increased sensory input
tranquillizers
muscle relaxants
anti-depressants.
aversive conditioning
cognitive dissonance
desensitization
hypnosis
religion
existentialism
dynamic
operant
family ("games")

Common concepts:

Input: reducing "pain-like" stimuli

Output: enhancing incompatible responses

Principle: breaking associative links between old stimuli and pain responses.

The schema is valuable in that it not only illustrates the variety of phenomena covered by the concept of pain but also highlights the common principle basic to the various tactics for treating chronic pain. This is the common principle of dissociating stimuli and responses. Implied by this principle is the idea that pain is that association of stimuli with responses which results in an unpleasant experience which hurts a person and from which he wants to be freed. In his essay Sternbach does not use this definition of pain, namely that it is an unpleasant experience which hurts a person, but $I$ find it necessary to introduce this common description to throw light on what the five types of scientists mean when they use the term "pain" in their different areas of research. This definition allows for the variety of pain phenomena mentioned by Sternbach, but at the same time it makes the point that in each of these approaches there is a concern with pain. This concern. with pain is shown by the neurologist, for example, who severs a nerve to block an impulse on the-assumption that thereby he is treating a person for an-unpleasant experience which hurts.
I differ from Sternbach in that I want to start from everyday experience in which the experience of pain is a reality to which a variety of descriptions can be applied. I hold therefore that the word " $p a_{\text {In }}$ ' is not only an abstract concept applicable to a variety of phenomena, but that the variety of phenomena is itself the result of a variety of approaches to a reality called pain as it is pre-scientifically experienced. By means of these approaches the reality of pain is objectified into a variety of phenomena each with its own status and structure. Thanks to the variety of approaches to which a variety of phenomena corresponds the rich texture of the reality of pain can be expressed. Each approach has its own rules, and statements can be judged to be right or wrong according to these rules and in terms of the consistency of their application. Each forms a language-game of its own, but no method should claim to be the only language-game, the only approach, the only strategy, possible in coping with the reality of pain. The neurological phenomenon, for example, does not do the work of the psychologicajphenomenon and the psychological phenomenon canno take the place of the neurological phenomenon. Both are necessary if we want to understand the reality of pain.

I have already pointed out that a variety of descriptions of pain is possible, but instead of dealing with as many descriptions as are possible I propose that we reduce them to three types of description. By doing this I am really constructing a philosophical model of man. As a philosopher I see no other way out of the complexity of descriptions available to us. If one takes as starting point that a human being is in pain or that pain is in the human being, then one should allow for at least three main descriptions of man which will correspondingly be applicable to pain. These three kinds of descriptions are based on the traditional distinctions between body, mind and person. I am proposing that we take a human being to be a reality of which it is possible to give descriptions in terms of body-language, mind-language, and person-language. By "body" I mean the physical and anatomical dimension of man, by "mind" the experiencing and conscious dimension, and by "person" the meaning-giving and social dimension. Many descriptions are possible within each dimension, but I choose the following three methods as representative of each of the three kinds of descriptions, namely, neurology, psychology and philosophy. According to me one can give three equaly basic descriptions of man in either neurological, psych logical, or philosophical language. Corresponding to these three languages as applied to the reality of a human being, there are three objectifications or structurings of man possible, namely, the phenomenon of body, the phenomenon of mind, and the phenomenon of person. These three objectifications of the reality of a human being, having as their purpose three different kinds of research about the same reality, can also be seen as abstractions, that is, as structures abstracted from the concrete reality of everyday experience. for the purpose of research and understanding.

These remarks on the reality of a human being can also be applied to the reality of pain in man. Pain can also be approached in three different ways depending on whether one describes pain in terms of body, mind or person. The reality of a human being in pain can be described in neurological, psychological, or philosophical language. I claim that, by commanding all three languages about pain, we not only enlarge our picture of what it means to be a man in pain, but we also improve our chances of helping him.

In order to give more content to this theory of the threefold description of man in pain $I$ intend dis- 
cussing systematically the neurological, the psychological and the philosophical language-games insofar as they throw light on the reality of pain.

\section{NEUROLOGICAL LANGUAGE-GAME}

Within the neurological language-game there are three theories of pain which deserve our attention. All three theories are good examples of the method used in neurology and correspondingly of the kind of object the neurological phenomenon is.

\section{Specificity theory}

For a long time the neurology of pain was dominated by a theory of sensation according to which different sensations excite different nerves. It was thought that "specific tracts in the nervous system had specific functions and projected to specific cortical regions". (de Villiers, 1977). This theory assumed a fixed, directline communication system from the skin to the brain enabling a specific one-to-one relationship between a ertain stimulus dimension and a corresponding psychoigical dimension. According to von Frey, who distinguished four cutaneous sensory modalities of touch, warmth, cold and pain, information is carried from four kinds of stimuli tranducers in the skin along four pathways to four specific receivers in the brain.

The specificity theory is rejected on the basis of psychological evidence (many psychological variables beside sensory input qualify pain), clinical evidence (the phenomenon of phantom limb pain) and physiological evidence (there is no evidence for the four modalities isolated by von Frey. There are specific receptors but they are more "plastic" than he suggested). Experiment has shown that there is differentiation of sensory receptors which "show an infinite degree of variability in their sensitivity to stimuli from the environment". (de Villiers, 1977). According to Noordenbos "pain may arise from virtually any type of stimulus or may be the result of afferent patterns which may travel via any available pathway". (Baken, 1968).

\section{Pattern theory}

According to this theory the basic determinants of pain are stimulus intensity and central summation. This theory gives content to remarks such as "pain is summation" (Sherrington) and "pain is too much" Noordenbos). Reacting against the one-to-one relationaip between stimulus and pain, pattern theory introduces the concept of the patterning of the input. It interprets sensation therefore not in terms of specific information received but in terms of spatial and temporal patterns of nerve impulses received by the central nervous system. The patterned information is made available to the central nervous system by a network of specialised receptors which translate what happens on the periphery on behalf of the centre. According to Melzack (1973) "the (peripheral) pattern theory fails to provide an adequate account of pain mechanisms. It does not recognise the facts of physiological specialization. It does not specify the kinds of patterns that might be related to pain. It provides no hypothesis to account for the detection of patterns by central cells." The psychological and clinical evidence mentioned as criticism against specificity theory also apply to pattern theory. The pattern theory, however, does have the virtue that previously experienced tempero-spatial patterns can be learned and remembered and recognised.

\section{Gate-control theory}

The third theory, known as the gate-control theory, combines elements of both specificity and pattern theories. It allows for specialisation and patterning. To this it adds the influence of psychological processes. In the words of Melzack (1975): "Basically, the theory proposes that a neutral mechanism in the dorsal horns of the spinal cord acts like a gate which can increase or decrease the flow of nerve impulses from peripheral fibres to the central nervous system. Somatic input is therefore subjected to the modulating influence of the gate before it evokes pain perception and response. The degree to which the gate increases or decreases sensory transmission is determined by the relative activity in large-diameter (A-beta) and small-diameter (A-delta and $\mathrm{C}$ ) fibres and by descending influences from the brain. When the amount of information that passes through the gate exceeds a critical level, it activates the neural area responsible for pain experience and response."

One of the assumptions made by this theory is the introduction of "filters" that modify impulses that arrive. It also allows for psychological processes to influence pain perception by acting on the gate-control system. Nevertheless, many problems are left unsolved. For example: What is the nature of the psychological phenomena? And how can their influence be translated into neurophysiological language?

These remarks on the neurology of pain illustrate the logic of the neurological language-game. What strikes a philosopher is the following: the methods used, the inevitability of hypotheses, the introduction of metaphors (such as pathway, gate, and filter), and the realisation that in addition to neurological concepts mental concepts are necessary for an adequate description of pain.

In his discussion of these three theories de Villiers (1975) concludes that "we do not experience pain at one site in the nervous system but throughout its' entire structure from the simplest sensory receptor: to its 'highest centres' in a complex interaction of intensity of stimulus and psychological reaction". Rejecting the validity of isolationist concepts such as "physical pain" and "emotional pain" he calls for a concept of pain which sees pain as "a total experience of a particular personality".

\section{PSYCHOLOGICAL LANGUAGE-GAME}

The psychological language-game can be illustrated in terms of three themes: firstly, the psychosomatic aspect of pain; secondly, the dimension of suffering; and thirdly, the influence of mind on body. The problem discussed under the psycho-somatic aspect of pain is related to pain having an emotional dimension to it. The second section looks at suffering as the fact of undergoing pain as a total experience. The third theme discusses the ways in which mind can influence the quality of the pain experience.

\section{Psycho-somatic aspects of pain}

In the previous section we have already drawn attention to the fact that neurological concepts were found to be inadequate in describing pain. Mental concepts were felt to be necessary in filling in the picture. Rather than speaking of physical pain and emotional pain we decided to talk about the total experience of pain to which both neurological and psychological descriptions are applicable. According to Sternbach (1968): "It is not pain which is mental or physical, functional or organic, psychic or somatic, but our ways of thinking about pain and the svstems of terms we use to describe pain which may be so dichotomized. All pain can be described in both languages, the psychological and physiological. Pain itself is not one or the other. But because pain can 
be described in both mental and physical terms, pain is truly a psychosomatic concept. From this point of view all pain is real; and all pain is also psychosomatic since both mental and physical descriptions are possible."

Trigg (1970) discusses this "paradox" of pain in the following way: "It is a sensation in so far as it can be localized and has its origin in a stimulus, and it is an emotion in so far as it disturbs one and makes one think of it as bad in some way. The paradox is immediately removed if the two strands are separated, and it is realized that the usual experience of pain involves both a sensation and an emotion directed at it." Pain refers to the whole pain experience which is a combined sensation and emotion experience.

\section{Suffering}

Suffering can be described in terms of the bearing or undergoing of pain, distress and injury. It is a human reaction to many kinds of events of which pain is but one. In the context of this essay the emphasis will be on the undergoing of pain as the unpleasant experience which hurts a person.

The psychological language-game stresses the role of consciousness in the experience of pain. This has already been seen in the previous section on the psycho-somatic aspect of pain in which sensation was linked to emotion. In this section I want to look at the fact that pain can infiltrate and occupy the whole of consciousness and cause suffering. Tichener makes this point in respect of toothache: "The pain of a toothache is localized at a particular place, 'in the tooth'; but the unpleasantness of it suffuses the whole of present experience, is as wide as consciousness. The word "pain" experience." (Melzack, 1973).

Metz (1975) suggests that because of this aspect of pain, namely that it infiltrates the whole of consciousness, we should take the disruption of human existence as frame of reference for an analysis of pain. Descriptions of pain experience reflect the intensity of this disruptive experience, for example: "The pain is so excruciating, I wish I were dead"; "the pain drives me mad"; "the pain embitters my life"; "the pain engulfs me"; "I dread the moment the pain returns". This last example points to an aspect of pain which also deserves attention, namely, the extent to which anticipation of pain can be seen as its worst aspect. There are cases in which anticipated pain imposes more suffering than the actual experience of the "painful" event. In these cases past experience and anxiety will place a crucial role.

Sternbach (1968) distinguishes between brief and chronic pains. In the case of a brief pain the stimulus is external, one tries to avoid it and a psychological distance is possible. "With chronic or inner pains there is no object to regard, or to avoid. The pain overwhelms us. We cannot place a psychological distance between ourselves and the hurt, and we are not merely threatened, but invaded and oecupied. It is not any longer a matter of having a body that has a hurt member, but we are a body that is almost entirely pain."

In this state one usually experiences loneliness, the feeling of being abandoned, and the feeling of being punished. Sternbach (1968) relates these experiences to pain-as-punishment phantasy. Whatever the nature of these experiences one cannot deny that they do accompany the undergoing of intense pain. But it need not be the case. The suffering person can find various strategies to cope with suffering as will be mentioned in the section on the philosophical language-game.

In this context it can be pointed out that not only can suffering be interpreted in various ways, but that even the relation between pain and suffering is not one of exact proportion. It depends on many psychological factors which pain and what amount of pain causes suffering. According to Hick (1968): "The extent to which a given quantity of the pain sensation causes us to suffer, and comes to determine the quality of our consciousness, varies enormously both from person to person and from time to time for the same person." This problem will be discussed in the next section.

\section{The infuence of mind on body}

The third psychological theme concerns the way in which the mind influences the quality of the pain experience. This has been discussed in various ways by many writers. I limit myself to a few examples from which, I hope, it will be clear what was implicit in the two previous sections, namely that pain is not merely the having of certain sorts of sensations, but also a response to these sensations, a taking up of certain attitude towards them. In this sense pain is relational concept. The kinds of relations which are in volved will be discussed in the rest of the essay.

The psychology of pain can be illustrated by a variety of examples taken from the following areas: ethnic and cultural patterns and their influence on the experience of pain, self-torture ceremonies, the death of martyrs, the role of past experience, attention, anxiety, depression, suggestion (placebos), audio analgesia, hypnosis, motivation, and the conscious interpretation of the significance of pain.

The first question that one can ask in respect of all these cases is: how does the mind influence the body? How do psychological factors influence pain? One way of answering this question is to describe the processes in terms of neurological language which makes use of the metaphor of the neurological gate being either closed or opened by a process initiated by the mind. This process results in either preventing the transmission of noxious impulses in positive attitudes (for example, motivation) or enhancing their transmission in negative attitudes (for example, anxiety). Bonica (1978b) argues: "In view of the decent data, it is not taking an unreasonable degree of scientific license to suggest that various emotional, motivational, and affective factors can stimulate parts of the brain which, through corticofugal impulses, have the capability to prevent transmission of noxious impulses the dorsal horn and at different levels of the neurax On the other hand, under appropriate conditions psychologic factors can 'open the gates' at various levels of the neuraxis and thus enhance transmission of noxious impulses to the brain with consequent greater pain experience." This exposition does not answer the question of the nature of the initial mental stimulation of neurological parts of the brain. Nevertheless, it succeeds in highlighting the philosophical problem of the relationship between mind and body.

Whatever interpretation we give of these phenomena, the problem of mind influencing body remains. I quote a few examples to illustrate this point.

The first example shows how the mind can play a determinative role in generating pain. Bakan (1968) reports the following experiment. An investigator induces pain in the phantom limb of a patient "by referring to some cause of anxiety in the patient's interpersonal life . . . the possible reaction of his wife to the disfigurement, his fear that she might leave him and, less noticeably, his mother's illness. When these topics were introduced into the discussion, the patient grasped the amputation stump, jerked his head toward the right shoulder and then complained of having pain. This 
psychologic equivocation of pain occurred repeatedly; The introduction of these topics, psychologically painful to him, led him to behave in this manner."

The second example, is taken from the practice of hypnotism. Spiegel, an exponent of medical hypnotism, talks of "the art of handling pain" which is taught to patients (for example, cancer and migraine patients) so that the "tyranny of pain" is removed: "The patient learns to superimpose a feeling of numbness over the pain area, and to filter the hurt out of it. He does this through a focused awareness, like being absorbed in a task." (Time, 1d69). It is pointed out that in these cases "the signals received and transmitted by the nerve fibres are not altered. What is changed is the mental perception and processing of pain."

The third example illustrates the conscious interpretation of the significance of pain and anticipates the next main section on the rolc of the meaninggiving activity of the person involved. It is the wellknown example reported by Beecher. "At Anzio the wound was often apparently construed as a good thing, sor it meant release from an intolerable situation. It heant the war was over for the individual. There, only one-quarter of the severely wounded men (although clear mentally ...) had pain enough to want anything done about it ..." (Hick, 1968) According to Sauerbruch and Wenke (1963): "The sufferer's inner attitude can exercise a powerful formative and transformative effect. How a sufferer supports the pain, how he copes with the pain experience, often depends on his inner attitude."

The role of attitudes in the experience of pain is the theme of the next section on the philosophical languagegame.

\section{PHILOSOPHICAL LANGUAGE-GAME}

The philosophical language-game was already present in the previous analyses. In the neurological analysis it showed itself in the discussion of the epistemological problem of linguistic parallelism. The psychological analysis produced the following philosophical problems: the relationship between cmotion and sensation, the influence of mind on body, and the attitude of a person to suffering. In this section other philosophical considerations will be discussed while the main threads of the argument will be kept in mind. The central theme in this section can be seen as the moral dimension of being a person which includes the problem of responsibility and the task to give meaning to the fifferent kinds of pain.

' I will concentrate mainly on the task of giving meaning to pain and discuss other problems as they follow logically from this analysis. There are three main areas that have to be taken into account: firstly, the exploration of meaning in terms of the biological function of pain. In this context pain is interpreted as a sign which functions as a signal warning man of a disorder in the body. Secondly, the exploration of meaning in terms of the psychological function of pain. Here pain is interpreted as a sign which functions as a symbol waming man of a disorder in the mind. Thirdly, the exploration of meaning in terms of the philosophical function of pain. In the third language-game pain is interpreted as a sign which functions as a "significance" warning man of a disorder in the moral sphere. This can take on many forms, for example, disorders in personal integrity, interpersonal relationships, social structures, and in the way in which a person relates to the question of the meaningfulness of life and death.

\section{Biological Function of Pain}

Neurologically pain is said to be produced by a strong stimulus which tends to disorganise and threaten destruction of the tissue. Hick (1968) remarks as follows: "It has long been observed that the pain-receptor system is markedly less sensitive than the other sensory systems, with the result that pain is caused only by stimuli powerful enough to damage, or to threaten to damage, the body. Pain, says J. D. Hardy, 'results from noxious stimulation which indicates the beginning of damage to the pain-fibre ending'."

In terms of this description one can say that pain has the biological function of a warning signal, a function of such importance that it has been described as "a benefactor to all living things". Balme mentions the three following protective functions: "In the first place, pain serves as a means of alarm, drawing our attention to injury or disease of which we might not otherwise be conscious .... In the second place, pain acts as an invaluable deterrent, preserving us from experiments of a dangerous or infurious nature

In the third place, the sense of pain helps to create that condition of voluntary immobilization of an inflamed or injured part which the peripheral sympathetics are attempting to secure, and which is so essential a factor in bringing about a cure." (Hick, 1968).

Other writers have rejected this view of pain as a benefactor. Leriche speaks of "this false conception of beneficient pain". (Hick, 1968).

It is pointed out that "pain is by no means always proportional to the gravity of the danger to which it relates" (for example, in the case of a toothache). A second argument is based on the fact that the pain caused by fatal disorders, for example cancer, comes too late. A third argument points out that there is no point in a warning if it is not possible to profit from the warning outside the availability of modern medicine and surgery.

These arguments, however, do not invalidate the view that pain can be seen to have a beneficient function as a warning signal. It helps man to manage his life in the external environment and to interpret the signals of acute symptomatic pain as warnings. However, when it comes to chronic pain, the interpretation of pain in terms of a positive biological value is inadequate. The view of pain's biological function must make way for the problem of pain as human suffering in terms of psychological and philosophical meaning.

\section{Psychological Function of Pain}

In the case of biology pain was interpreted as a signal which warns the organism of a somatic disharmony. Within the context of the psychological language-game pain can be seen as a symbol which warns the person of a mental disharmony. In comparison with pain as a signal which reveals a somatic disharmony, pain as a symbol conceals a mental disharmony which has to be discovered. It has the character of a mask which has to be interpreted indirectly.

Buytendijk (1962) discusses examples of pain experiences which mask experiences of anguish, unfulfilled longings, violation of one's sense of justice, guiltconsciousness, etc. He interprets these pains in terms of man's discovery that in these situations he is thrown back onto his own resources. This results in a feeling of impotence which overpowers man and he soon finds himself in pain. In these cases the pain is clearly an expression of the state of impotence caused by any of the above mentioned experiences. This is clear to the psychiatrist but not to the patient. The task of the psychiatrist is to reveal to the patient that the mental disharmony is the cause of the pain. To convince the patient of the truth of this insight is sometimes very 
difficult, for the patient can identify himself with a painful role which becomes "the only answer to a life too painful in other ways." (Spiro, 1976).

Szasz (1957) speaks of the symbolic meaning of pain and discusses the problems which confront the psychiatrist in probing the symbol for information about the mental state of the patient. In many instances the same kind of pain symbolises different disharmonic conditions. He gives some examples of mental disharmonies which have a social dimension to them. A girl's pain is interpreted as a sign of her experience of loneliness after the death of her parents, and of her feeling of being rejected by members of her family resulting in a disguised cry for help. A man's pain becomes a sign of his inability to cope with the transition from naval service to civilian life; unconsciously he projects into pain both his frustration and his aggression against the authority which "let him down". Of this patient Szasz (1957) says: "The functional value of the symptom for the patient was readily apparent. Indeed, it seemed as if all significant issues in his life were translated, so to speak, into the language of pain and were then expressed in such a manner that neither the patient nor those to whom he addressed himself really knew what he was saying." The way in which he analyses and describes these cases allows one to speak of pain itself as a symbolic language which has to be decoded by the doctor. The example of the patient unable to adapt himself to the social structure is decoded by Szasz (1957) as follows: "The symbolic transformations which the concept 'pain' has undergone in this case may be summarized as follows: (1) The pain experience is an expression of a need for help (thus, also an intrapsychic defence against anxiety). (2) The communication of pain is a request for help. (3) When the request is frustrated, the persistence of the pain becomes a symbol of being rejected: 'It still hurts . . (4) The repeated complaint of pain is also a disguised form of aggression (retribution) against the frustrating, rejecting authority (physician, Navy, parent, etc.)."

In our analysis of the biological function of pain we described. it as a signal warning the patient of a threat to the body. In this analysis of the symbolic meaning of pain, pain is seen as a language in which the person expresses symbolically his request for help, his complaint about unjust treatment, his attack on authority, his frustrations, anxieties, unfulfilled longings, etc. In this sense pain has a communicative aspect. It is in this context that we can see pain as a mask which symbolically introduces us to the human being in pain. This remark throws light on the motto of this paper: "I have put on these masks to show you my face". If we do not succeed in interpreting the masks we will not succeed in understanding and healing the person who cries for help.

\section{Philosophical Function of Pain}

In the biological context pain was seen as a signal of disharmony in the body. In the psychological context it functioned as a symbol of disharmony in the mind. In the philosophical context it can be seen as a "significance" which warns of a disharmony in the moral order which calls for an intentional act of personal involvement. This disorder can express itself in terms of disharmonies in personal integrity, relationships, and in social structures. In certain cases the pain becomes the opportunity for ultimate concern in which questions about the ultimate meaning of life are raised. In all four cases the liberating act of personal involvement is crucial. In a sense one can say that the philosophical function of pain is its chal- lenge to a person to become personally involved in what is happening and to respond in a creative way through meaning-giving activity. There is indeed no easy way out of the pain situation.

Bakan (1968) introduces an interesting model to illustrate his concept of the responsibility of the individual in respect of pain, which is worth mentioning in this context. He proposes that the conscious ego should be seen as the major telic centre of the human organism. The word "telic" is derived from "telos" which means purpose or goal. The human organism is seen as an organic whole with a hierarchy of telic centres under the dominion of the conscious ego as the major telic centre. Pain is described as a "manifestation of telic decentralization", in which a lower telos takes on more importance than it should and consequently distorts the balance. Pain can then be seen as "the demand on the conscious ego to work to bring the decentralized part back into the unity of the organism. Pain is the imperative to the ego to assume the responsibility of telic centralization ... (Bakan, 1968). This is only a model, but it is a useful model for it highlights thef creative role of the conscious ego. It is this respon-4 sibility of the person in respect of pain that $I$ intend discussing in the next four sub-sections.

\section{Disharmony in Personal Integrity}

Pain can play an important role philosophically in calling a person to become involved in the moral quality of his life by taking responsibility for his deserved pain, and in illustrating that he can control his life courageously in cases of undeserved pain.

Illich (1975) describes pain in positive terms by stressing the important moral role it can play. He talks of the healing power of pain and the moral nature of patience in suffering. He can do this because he sees pain as an invitation to the suffering person to ask questions about the quality of his life. According to him "medical civilization tends to turn pain into a technical problem and thereby to deprive suffering of its inherent personal meaning. People unlearn to accept suffering as an inevitable part of their conscious coping with reality and come to interpret every ache as an indicator of their need for the intervention of applied science." (Illich, 1975). He defines suffering as "an autonomous performance under the impact of pain". The expression "autonomous performance" refers to the person's responsible relationship to his pain, his willingness to accept the challenge of pain.

In order to accept this challenge the patient needs a culture, a context of values, to help him interpret the pain. One can follow Illich in saying that to suffer pain is to raise a question, and the context of shared values helps one to articulate pain in a meaningful way. In the words of Illich (1975): "The act of suffering is shaped by culture into a question which can be stated and shared." To be divorced from these shared values is to be lost in a very real sense and to become a victim of one's pain.

Boeyink (1974) speaks of "redemptive pain insofar as it enhances and maintains the moral elements in life, whether it be virtue (courage), freedom or the fulfillment of moral obligations to one's fellows". In the case of accepting deserved pain one can develop a sense of responsibility for that pain, and change one's lifestyle accordingly. "A sense of justice requires the recognition of responsibility for the pain of one's making. Such pain is the summons to fidelity to one's self and physical well-being, calling one to re-order one's life." (Boeyink, 1974). In this context pain-killing drugs, anaesthesia and antacid tablets can have a negative effect in convincing the patient that it is not 
vet necessary for him to change his unhealthy living. In the case of accepting undeserved pain the suffering can also have a redeeming quality, particularly for others. This act of courage enriches the person and sets an example for others. It illustrates the fact that man can control his own life. It can also lead to a sense of community among the sharers of pain in settings such as hospitals. Acceptance of undeserved pain can furthermore diminish suffering because it takes the place of guilt, grief or sadness which themselves also cause suffering. (Boeyink, 1974).

\section{Disharmony in Interpersonal Relationships}

In the discussion of the psychological function of pain I referred to the example mentioned by Szasz (1957) of the girl whose involvement in pain was caused by her experience of loneliness after the death of her parents and by her distorted interpersonal relationships. If one assumes that human life has a relational structure, this kind of distortion can easily je understood. Pain can then indeed be a symptom of disturbed dialogue. Metz $(1964,1975)$ has done important work in showing that pain takes place in an intersubjective world and that one must pay attention to the role of disturbed dialogue in understanding pain. The dialogue with the psychiatrist can be of help in restoring the dialogue with the world around the patient by helping her to understand the situation of which she is inevitably a part. This dialogue with the psychiatrist also underlines the importance of dialogue in general, which points to the fact that man has no direct access to himself but only through the world and through the eyes and reactions of other human beings. In a certain sense man is a gift to himself through the acts of others.

Metz (1975) relates the case-history of a patient with an extreme form of trigeminal neuralgia. This was his second severe attack. The first attack of pain was terminated by severing the nerve. The pain was so intense the second time that he could not speak. The neurosurgeons decided on surgery, but before this operation could be performed Metz had the opportunity to treat the patient. It was only when the history of the pain was contextualised within the history of the patient that the causes of the pain were discovered. For various reasons this person isolated himself socially. $\mathrm{Yis}$ relationship to his wife was reduced to silence. When Metz realised that the attacks of neuralgia occurred during periods of social isolation he decided that the cause of pain was disturbed dialogue. The patient and wife were confronted with this interpretation. They decided to attend the sessions conjointly. The patient was willing to communicate by writing questions and answers on a slate. Gradually they started talking to one another, and gradually the pain disappeared.

The first time the patient was healed by surgery, the second time by breaking through his social isolation and by overcoming disturbed dialogue. Not the doctor but the wife as the main partner in the dialogue played the crucial role in the patient's recovery of health, illustrating clearly how a disorder in interpersonal relationship can cause pain, and how a restored dialogue can cause pain to disappear.

\section{Disharmony in Social Structure}

We have seen that pain is not an abstraction outside a person. But neither is a person an abstraction outside human relationships and social structures. (Berger, 1967). This throws light on the fact that in our discussion of the psychological language-game personal examples were given which involved interpersonal relationships and social structures.

Szasz (1957) gives the example of the man who was treated for persistent abdominal pain over a long period without any change in his condition. Psychiatric treatment revealed that his pain had to be linked with the fact that the termination of his tour of naval duty was drawing near. The transition to civilian life entailed an important change in his total life pattern. He found a job similar to the one he did in the navy. At no stage did he feel that he was confronted by a "problem". But in actual fact he was looking for guidance. In the absence of help he experienced a rejection of authority which in his case was the organisation which "rejected" him after many years of service. In this example the pain becomes a sign of his inability to cope with the transition from naval service to civilian life. His frustration and his aggression against the authority which "let him down" were unconsciously projected into pain. This case could be seen merely as an example of a person whose pain reflects his inability to adapt himself to new situations. I want to suggest that there is also a social dimension to this problem, namely, how to relate to one's work which is an involvement in an organisational and social structure.

Modern social philosophy gives priority to the fact that man is a social being and holds that social structures qualify human behaviour. In this they follow the view of Marx that "man is a network of social relationships" co-determined by social structures. These structures also influence the way in which a person understands himself and what happens to him. If these structures are not conducive to healthy living conditions and if they do not provide for the basic human needs of all citizens and for the full development of their potentialities, and if these structures furthermore take on an authoritarian nature and stifle human relationships, causing different kinds of alienation, then the individual will surely be influenced to experience and define himself in a negative way. In such cases the experience of pain and suffering will inevitably reflect the negative social structures.

Manganyi, a black psychologist, talks of the way in which the social structures in South Africa are reflected in the body image of the black man. The body image is the intemalised conception an individual has of his physical self, and because of the negative social structure the black man has a negative conception of his black body. This leads to "pain" and "suffering" which should be overcome. One way of doing this is to reject the white view of the black body as expressed in social structures and as internalised by the Blacks. In his own words: "We have to eradicate the negative sociological schema of the black body as prescribed by whites." (Manganyi, 1973).

\section{The Problem of Ultimate Meaning}

In all these cases it is possible that the situation of pain is also used to raise the problem of the ultimate meaning of life. This usually happens in cases of terminal illness. A good example of this type of consideration is found in "The Death of Ivan Ilyitsh" (Tolstoy) in which the realisation of the inevitability of one's own death triggers off a fundamental questioning of the quality of one's life. If one agrees with Bakan (1968) that "pain is also indicative of the fact that death will eventually ensue", and that "each pain provokes the question, 'Does this mean that I will die?" then one can imagine many situations in which pain becomes "the touchstone of ultimate concern".

If one links ultimate meaning with the reality of 
love it not only has implications for the life of the patient, but it also throws light on the quality of caring for people in sociable surroundings. The point is to help them to overcome the loneliness of pain, not to feel cut off from humanity, and to experience that suffering is not only an individual problem which isolates but a human problem which calls forth love. Sternbach (1968) draws our attention to the fact that "the relief of pain is typically associated with comfort, love, and expressions of caring, and with the reduction of anxieties related to the withdrawal of love."

It is in the context of the problem of the ultimate meaning of life that it makes sense to look at the plurality of answers given by world religions to the questions of pain and suffering (Bowker, 1970), and to tackle the problem of theodicy (Hick, 1968) which sets out to reconcile a good God with an evil world.

\section{IMPLICATIONS OF'THIS VIEW}

These philosophical considerations on pain have various implications worth noting. I discuss three of these, namely the implications for theory, method of research, and therapy. My remarks on these themes will be arranged under the following headings: the importance of an adequate pain theory, the need for an interdisciplinary approach, and the necessity of a multiple therapeutic strategy.

\section{Importance of an Adequate Pain Theory}

The philosophical language-game has shown how important an adequate pain theory is, not only for the medical scientist and practitioner but also for the patient, his family and friends. All of them must realise that the whole man is involved and that in cases where pain is clearly a human cry for help the liberation from pain cannot be achieved without a realisation of this fact. In this sense there is a close link between curing and caring.

In both his books on pain Metz $(1964,1975)$ stresses the importance of an adequate theory of pain, for in many cases patients suffer pain because of the application of an inadequate theory. He relates examples of patients who were operated on many times for the same complaint without success. Instead of giving heed to the sound advice of the doctor to bring the experience of pain in agreement with the medical assessment of the case one patient demanded a third operation. Again without success. According to Metz (1975) this patient was a victim of a physiological pain theory which does not allow for the possibility of pain without a physiological cause. Pain is then only described in terms of a bodily defect and not as something directly linked with the situation in which the patient lives. The patient sees his pain experience in terms of a pain theory prevalent at that time. And, according to Metz, this is not difficult to understand, since we live in an age in which "scientific" insights constitute the world-view for man. It prescribes the way in which man experiences and understands his life. In this sense a pain theory prescribes for a patient how to experience and understand his pain. On the basis of these arguments Metz calls for a broader approach in order to help all concerned to come to grips with the problem of pain in a more human way. It is only by listening with an open mind that we can discover the person in the pain.

\section{The Need for an Interdisciplinary Approach}

A serious search for an adequate theory of pain will inevitably lead to a realisation of the limitations of specialisation and consequently of the need for an interdisciplinary approach to the problem. (Graham, 1967). Bonica (1978a) mentions three reasons for inadequate management of chronic pain: lack of knowledge, inadequate application of current knowledge, and problems of communication. In his discussion of the inadequate application of current knowledge and of the importance of dorology (the science of pain), he touches on the problem of specialisation and the resul. tant lack of an interdisciplinary approach ("collaborative multidisciplinary research"). He points out that "the current progressive trend toward specialization is con. ducive to each specialist viewing pain in a narrow, 'tubular' fashion. Thus, the anaesthesiologist attempts to treat all patients with nerve blocks, the neurosurgeon by cutting the so-called pain pathways, the psychiatrist by traditional psychotherapy, etc. This type of 'tubular' vision is particularly likely to occur when a specialist practices alone and sees these patients in isolation. The factors preclude viewing the pain problem with the perspective of the many diagnostic and therapeutic strategies which may be applicable to the particular, problem in choosing which are best for the particula
patient." (Bonica, 1978a).

It would be a great pity if the insight into the importance of a more comprehensive theory gains ground while research is continually conducted on the basis of separation. I do not know what the present policy and practice is with regard to interdisciplinary approach. Graham (1967) talks of the harmful practice of separation which is deplored by the groups involved but which nevertheless continue to exist. Whatever the state of affairs is, my analysis calls for an adequate theory of pain translated into an interdisciplinary programme of pain research, a truly critical co-investigating dialogue, resulting in a multiple therapeutic strategy.

\section{The Necessity of a Multiple Therapeutic Strategy}

The remarks made by Bonica in favour of interdisciplinary research should sound familiar by now. In the previous sections of this essay I have paid attention to the advantage of a plurality of pain descriptions in comparison with a "tubular" approach. We have seen that a pluralist approach introduces one to a rich variety of facts that would otherwise not be available. It makes us more flexible in our approach to the reality of pain. But it not only helps us to broaden our understanding but also to give us better therapeutic strategy. If we can play mor language-games and use more kinds of descriptions we should be capable of coping better with a pain situation.

A multiplicity of descriptions already points the way to a multiple strategy in therapeutic situations. Sternbach (1968) speaks of the neurological, physiological, behavioural and affective approaches as four explanatory systems which all have implications for medical practice. I have reduced the plurality of descriptions to three language-games and in terms of this analysis one will have to structure one's therapy along the lines presented by the three phenomena of body, mind and person. I have said that a human being is a reality which can be described in neurological, psychological and philosophical languages. This remark has also been made about pain. Pain is also a reality to which neurological, psychological and philosophical descriptions are applicable. The implication of this for therapy is that one will have to ascertain in each situation what strategy to apply, for example, when to apply surgery, when psycho-analysis, and when dialogue.

In stressing the need for interdisciplinary research, the importance of a plurality of descriptions, and the necessity of a multiple therapeutic strategy one might 
lose sight of the crucial role of an integrated approach to a person in his pain. Therefore, I would like to conclude by linking therapy with integration. If integration is our key term then the task of therapy would be, not to limit the reality of pain to the context of the body and to the context of the mind, but to place it in the appropriate context of the fullness of human existence. Formulated in another way: the pain should he placed in the body and in the mind while both body and mind are integrated into the world of persons whose lives are threatened and who are in need of help. Therapy should therefore be integrated into the attitude of caring for persons. And the purpose of this caring is not primarily to be in the service of the conservation of the human body, but rather in the service of the destination of human life. It is in the framework of this philosophical language-game that one realises that pain is more than something to be abolished. For human beings are more than patients that have to be treated. They are persons who are threatened in their existence and are crying for help. Therefore the philosophy of ain views therapy of pain as a caring in terms of the destination of human life. And taking the words of Camus into account that "there must be a destiny that does not have to wait on death" we might say that this question of human destination remains the final challenge for patient and doctor and friend alike. If a patient succeeds in seejng his pain in terms of significance and if his doctor and friends succeed in caring, then the pain experience can be said to have passed beyond the meaning of the Latin original poena, namely punishment, to the meaning of the Sanscrit root $p u$, namely purification.

\section{Bibliography}

Armstrong, D. M. (1962): Bodily Sensations. London.

Armstrong, D. M. (1978): "Between Matter and Mind", Times Literary Supplement, 183 - 184.

Bakan, D. (1968): Disease, Pain, and Sacrifice. Towards A Psychology of Suffering. Chicago: The University of Chicago Press.

Balme, H. (1939): The Relief of Pain: A Handbook of Modern Analgesia. London: Churchill.

Barber, T. X. (1959): Towards a Theory of Pain, Psychological Bulletin, 56.

Beebe-Center, J. G. (1965): The Psychology of Pleasantness and Unpleasantness. Russell.

feecher, H. K. (1957): The Measurement of Pain,

Pharmacological Review, 59 - 203.

Beecher, H. K. (1959): Measurement of Subjective Responses Oxford University Press.

Bendit, T. (1975): A Problem for Theodicits. Philosophy, $\mathbf{5 0}, 470-474$.

Berger, J. and Mohr, J. (1969): A Fortunate Man. The Story of a Country Doctor. Middlesex: Penguin.

Bettelheim. B. (1954): Symbolic Wounds. Free Press.

Boeyink, D. E. (1974): Pain and Suffering, Journal of Religious Ethics, 2, 85 - 98.

Bonica, J. J. (1953): The Management of Pain. Philadelphia: Lea and Febiger.

Bonica, J. J. (1978a): Chronic Pain: A Disease State of Major National Importance. Unpublished Paper.

Bonica, J. J. (1978b): New Information on Pain Mechanisms. Unpublished Paper.

Bowker, J. (1970): Problems of Suffering in Religions of the World. Cambridge: At the University Press.

Brena, S. (1972): Pain and religion: a psychophysiological study. Springfield: C. C. Thomas.

Buttrick, G. A. (1966): God, Pain and Evil Nashville: Abingdon.

Buytendijk, F. J. J. (1962): Pain: Its Modes and Functions: Chicago: University of Chicago Press.
Cannon, W. B. (1939): The Wisdom of the Body. New York: W. W. Norton.

Carter, W. R. (1972): Locke on Feeling another's Pain. Philosophical Studies, 23, 280 - 285.

Clark, O. (1973): Pain and Being: An Essay in Heideggerian Ontology. South Western Journal of Philosophy, 4, $179-190$.

Concordia, G. L. (1969): Medicine and the human Situation. Philosophical Forum, 8, 37 - 52.

Crouse, M. A. (1975): 'n Studie in die pynervaring en 'n pastorale hantering daarvan. Skripsie. Stellenbosch: Fakulteit van Teologie.

Crue, B. L. (ed.) (1970): Pain and Suffering. Springfield: C. C. Thomas.

Dare, C. (1970): An Examination of the Soul-making Theodicy. American Philosophical Quarterly, 7. $119-130$.

De Villiers, J. C. (1977): The Physiology of Pain. Unpublished paper.

Du Preez, J. P. A. (1974): The Scapegoat - A Psychological Discussion of the Significance of Suffering. Fort Hare Papers, 6, 3 - 17.

Elphinstone, A. (1976): Freedom, Suffering and Love. London: SCM

Evans, E. (1926): A psychological study of cancer. New York: Dodd, Mead.

Finn, P. R. (1971): Putnam on Logical Behaviourism. Mind, 80, 432 - 436.

Fitch, W. (1967): God and Evil. Studies in the Mystery of Suffering and Pain. London: Pickering and Inglis.

Fleming, N. (1976): The Objectivity of Pain. Mind 85, 522 - 541 .

Fordyce, W. (1976): Behavioural Methods for chronic Pain and Illness. St. Ĺouis: Mosby.

Gert, B. (1967): Can a brain have a pain? Philosophy and Phenomenological Research, 27, $432-436$.

Gibbs, B. (1969): Putnam on brains and behaviour. Analysis, 30, 53 - 55.

Godlovitch, R. (1971): Animals and Morals. Philosophy, 46, 23 - 33.

Gotter-barn, D. (1975): Berkeley: God's Pain. Philosophical Studies, 28, 245 - 254.

Graham, D. T. (1967): Health, disease, and the mindbody problem: Linguistic parallelism. Psychosomatic Medicine, 29, 52 - 71 .

Hannington-Kiff, J. G. (1974): Pain Relief. London.

Hardy, J. D. (e.a) (1967): Pain, sensations and reactions. Hafner.

Hare, R. M. (1964): Pain and Evil. The Aristotelian Society, Supplementary Volume. 38.

Harris, M. (1974): Psychogenic aspects of facial pain. British Dental Journal, 136, 199 - 202.

Harrison, F. R. (1971): The Pain of R.-George, Robot. Southern Journal of Philosophy, 9, 371-380.

Hasher, W. (1971): Theories, Analogies and Criteria. American Philosophical Quarterly. 8, 242 - 256.

Hester, M. B. (1966): Wittgenstein's Analysis of 'I know I am in Pain'. Southern Journal of Philosophy, 4. $274-279$.

Hick, J. (1968): Evil and the God of Love. London: Collins.

Hinton; J. (1911): The Mystery of Pain, London: Hodder and Stoughton (1866).

Hinton. R. T. (1975): Is the Existence of Pain a Scientific Hypothesis? Philosophy, 50, $97-100$.

Hodges, M. and Carter, W. R. (1969): Nelson on Dreaming a Pain. Philosophical Studies, 20. 43 - 46.

Holborow, L. C. (1969): Against projecting pains. Analysis. 29. $105-108$.

Illich, I. (1975): Medical Nemesis. The Expropriation of Health. London: Calder and Boyars.

Jaffe, R. (1967): Conservatism and the praise of suffering. Ethics, 77, $254-267$. 
Keele, C. A. and Smith, R. (eds.) (1962): The Assessment of Pain in Man in Animals. London: Livingstone. Keele, K. D. (1957): Anatomics of Pain. Oxford: Blackwell.

Kitamori, K. (1966): Theology of the Pain of God. London: SCM.

Knighton, R. S. and Dumke, P. R. (eds.) (1966): Pain. Boston: Little, Brown and Company.

Kolb, L C. (1954): The painful phantom: psychology, physiology and treatment. Springfield: C. C. Thomas.

Kowal, S. J. (1955): Emotions as a cause of cancer. Psvchoanalitic Review, 42, 217 - 227.

Leriche, R. (1939): The Surgery of Pain. Tr. by A. Young. London: Baillière, Tindall and Cox.

Lewis, C. S. (1977): The Problem of Pain. Glasgow: Collins. (1940).

Lewis, T. (1942): Pain. New York: Macmillan.

Lifton, R. J. (1969): Death in life-survivors of Hiroshima. New York: Random House.

Livingston, W. K. (1947): Pain Mechanisms. New York: Macmillan.

Manganyi, N. C. (1973): Being-Black-inthe-World. Johannesburg: Ravan.

McKenna, A. E. (1958): The Experimental Approach to Pain. Journal of Applied Physiology, 13, 449 456.

McKenzie, J. C. (1968): The Externalization of Pains. Analysis, 28, 189 - 193.

Medvei, V. C. (1949): The mental and Physical Effects of Pain. Edinburgh: Livingstone.

Melzack, R. and Wall, P. D. (1968): Gate Control Theory of Pain. $11-31$ in A. Soulairac, e.a. (eds.): Pain. London: Academic Press.

Melzak, R. (1973): The Puzzle of Pain. New York: Basic Books.

Merskey, H. (1967): Pain psychological and psychiatric aspects. Williams and Wilkens.

Metz, W. (1964): Methode en Mensbeeld der Geneeskunde. Het verschijnsel pijn. Haarlem: De Erven F. Bohn.

Metz, W. (1973): Over lichamelijke pijn. Tijdschrift voor Pastorale Psychologie, 65 - 80.

Metz, W. (1975): Pijn, een teer punt. Een fundamenteel geneeskundig onderzoek. Nijkerk: Callenbach.

Montague, R. (1975): The Always-Painfree PainBehaver. Mind, 84, 47 - 62 .

Noordenbos, W. (1959): Pain. Problems pertaining to the transmission of nerve impulses which give rise to pain. Amsterdam: Elsevier.

Noren, S. J. (1974): Direct Realism, Sensations, and Materialism. The Southern Journal of Philosophy, 12, 83 - 94 .

Norton, D. L. (1972): 'Eudaimonia' and the paindispleasure arbument. Ethics, 82, 314-320.

Ochs, C. R. (1966): The sensitive term 'Pain'. Philosophy and Phenomenological Research, 27, 255-260.

Overduin, J. (1973): De Kunst van het Ziek Zijn. Kok: Kampen.

Palmer, D. (1975): Unfelt Pains. American Philosophical Quarterly, 12, 289 - 298.

Perl, E. R. (1971): Is Pain a specific Sensation? Journal of Psychiatric Research, 8, 273-287.

Petrie, A. (1967): Individuality in Pain and Suffering. Chicago: University of Chicago Press.

Pitcher, G. (1970a): Pain Perception. Philosophical Review, 79, 368 - 393.

Pitcher. G. (1970b): The Awfulness of Pain. Journal of Philosophy, 67, $481-492$.

Plessner, H. (1970): Laughing and Crying. A Study of the Limits of Human Behaviour. (Tr. by J. S. Churchill and M. Grene). Evanston: Norwestern University Press.

Prescott, F. (1964): The Control of Pain. New York:
T. Y. Crowell.

Puccetti, R. (1975): Is Pain Necessary? Philosophy, 50, $259-269$.

Redpath, T. H. (1971): Orofacial Symptoms in Psychiatric Disease. The Dental Practitioner, 21, 301-306.

Romanell, P. (1969): Medicine and the Precariousness of Life. Philosophical Forum, 8, 3 - 34

Roux, G. H. (1971): Die geneeskundige Etiek van Eerbied vir die menslike Lewe. Geneeskunde, 13, $217-220$.

Sanders, J. A. (1955): Suffering as Divine Discipline in the Old Testament and Post-Biblical Judaism. New York: Rochester.

Sarano, J. (1970): The hidden face of pain. Judson.

Sauerbach, F. and Wenke, H. (1963): Pain: Its Meaning and Significance. (Tr. by E. Fitzgerald). London: Allen and Unwin.

Sborowitz, A. (Hrsg.) (1974): Der leidende Mensch. Personale Psychotherapie in anthropologischer Sicht. Darmstadt: Wissenschaftliche. Buchgeselschaft.

Seifert, E. (1960): Der Wandel im menschlichen Schmerzerleben. München.

Shorpen, E. (1973): Pain-Pricks to the Body and Pain to the Mind. Philosophical Forum, 14, 53-79.

Smith, A. W. (1971): The paradox of pain. Shaw.

Solle, D. (1975): Suffering. Tr. by E. R. Kalin. London: Darton, Longman and Todd.

Soulairac, A., e.a. (eds.) (1968): Pain. London: Academic Press.

Spiro, H. M. (1976): Pain and Perfectionism - the Physician and the 'Pain Patient'. Medical Intelligence, 294, $829-830$.

Sternbach, R. A. (1968): Pain. A Psychophysiological Analysis. New York: Academic Press.

Sternbach, R. A. (1970): Strategies and Tactics in the Treatment of Patients with Pain. $176-185$ in B. L. Crue (ed.): Pain and Suffering. Springfield: C. C. Thomas.

Sternbach, R. A. (1974): Pain Patients: Traits and Treatment. New York: Academic Press.

Switzer, D. K. (1970): The Dynamics of Grief. Its Source, Pain. and Healing. Nashville: Abingdon.

Szasz, T. S. (1957): Pain and Pleasure. A Study of Bodily Feelings. London: Tavistock.

Szasz, T. S. (1962): The Myth of Mental Illness. London: Secker and Warburg.

Szasz. T. S. (1968): The Psychology of Persistent Pain: A Portrait of L'Homme Douloureux. 93-113 in A. Soulairac, e.a. (eds.): Pain. London: Academic Press.

Taylor, D. M. (1970): The logical Privacy of Pains Mind. 79, 78 - 91

Teilhard de Chardin, P. (1975): On Suffering. London: Collins.

Time (1969): Pain: Search for Understanding and Relief. Time, $56-57$.

Trigg, R. (1970): Pain and Emotion. Oxford: Clarendon Press.

Van den Berg, J. H. (1959/60): Het Menselijk Lichaam. Nijkerk.

Van den Berg, J. H. (1963): Pijn in een meervoudig leven. Hfst. 10 in Leven in Meervoud. Nijkerk.

Vesey, G. N. A. (1965): The Embodied Mind London.

Vesey, G. N. A. (ed) (1970): Body and Mind. London: Allen and Unwin.

Von Dürckheim, Von Karlfried Graf (1974): Die anthropoligischen Voraussetzungen jeglichen Heilens. pp 157-185 in A. Sborowitz (hrsg.): Der leidende Mensch. Darmstadt: Wissenschaftliche Buchgesellschaft.

Walker, K. (1970): Circle of life: a search for an attitude to pain, disease, old age and death. McGrath.

Way, E. L. (ed.) (1967): New Concepts in Pain and its clinical Management. Philadelphia: Davis. 
White, J. C. and Sweet, W. H. (1955): Pain. Its mechanisms and neurosurgical control. Springfield: C. C. Thomas.

Wierzinga, H. (1975): Verzoening met het Lijden? Baarn: Ten Have.

Wittgenstein, L. (1963): Philosophical Investigations. Oxford: Blackwell.

Wolff, H. G. (ed.) (1943): Pain. Baltimore: Williams and Wilkens.

Wolff, H. G. and Hardy, J. D. (1947): On the nature of pain. Physiological Review, 27, $167-198$.
Wolff, H. G. and Wolf, S. (1958): Pain. Blackwell Scientific Publication. Oxford.

Wood, E. (1962): A study of pleasure and pain. Theos publishing House.

Wordsworth, J. C. (1954): Pain and other Problems. London: Allen and Unwin.

Zborowski, M. (1969): People in Pain. San Francisco: Jossey Bass.

Zemach, E. M. (1971): Pains and Pain-feelings. Ratio, 13 Nr. 2, pp $150-157$. 